\title{
Biodegradation kinetics of toluene, $m$-xylene, $p$-xylene and their intermediates through the upper TOL pathway in Pseudomonas putida (pWWO)
}

\author{
Wouter A. Duetz, ${ }^{1}$ Bea Wind, ${ }^{2}$ Johan G. van Andel, ${ }^{2}$ Michael R. Barnes, ${ }^{3}$ \\ Peter A. Williams ${ }^{3}$ and Michiel Rutgers ${ }^{2}$
}

1 Institut für Biotechnologie, ETH Hönggerberg, HPT, $\mathrm{CH} 8093$ Zürich, Switzerland

2 Laboratory of

Ecotoxicology, National Institute of Public Health and the Environment, PO Box 1, 3720 BA Bilthoven, The Netherlands

3 School of Biological Sciences, University of Wales, Bangor, Gwynedd LL57 2UW, UK

\author{
Author for correspondence: Wouter A. Duetz. Tel: +41 16333811 . Fax: +41 16331051. \\ e-mail:duetz@biotech.biol.ethz.ch
}

\begin{abstract}
Pseudomonas putida mt-2, harbouring TOL plasmid pWWO, is capable of degrading toluene and a range of di- and tri-alkylbenzenes. In this study, chemostat-grown cells ( $D=0.05 h^{-1}$, toluene or $m$-xylene limitation) of this strain were used to assess the kinetics of the degradation of toluene, $m$ xylene, p-xylene, and a number of their pathway intermediates. The conversion kinetics for the three hydrocarbons showed significant differences: the maximal conversion rates were rather similar [11-14 $\left.\mathrm{mmol} \mathrm{h}^{-1}\left(\mathrm{~g}^{\mathrm{dry}} \mathbf{w t}\right)^{-1}\right]$ but the specific affinity (the slope of the $v$ vs $s$ curve near the origin) of the cells for toluene [1300 I (g dry wt) $\left.)^{-1} h^{-1}\right]$ was only $5 \%$ and $14 \%$ of those found for $\boldsymbol{m}$-xylene and $p$-xylene, respectively. Consumption kinetics of mixtures of the hydrocarbons confirmed that xylenes are strongly preferred over toluene at low substrate concentrations. The maximum flux rates of pathway intermediates through the various steps of the TOL pathway as far as ring cleavage were also determined. Supply of $0.5 \mathrm{mM}$ 3-methylbenzyl alcohol or 3methylbenzaldehyde to fully induced cells led to the transient accumulation of 3-methylbenzoate. Accumulation of the corresponding carboxylic acid (benzoate) was also observed after pulses of benzyl alcohol and benzaldehyde, which are intermediates in toluene catabolism. Analysis of consumption and accumulation rates for the various intermediates showed that the maximal rates at which the initial monooxygenation step and the conversion of the carboxylic acids by toluate 1,2-dioxygenase may occur are two- to threefold lower than those measured for the two intermediate dehydrogenation steps.
\end{abstract}

Keywords: BTEX, flux study, specific affinity, aromatic hydrocarbons, Michaelis-Menten kinetics

\section{INTRODUCTION}

Pseudomonas putida mt-2 was isolated in Japan from a $m$-toluate enrichment culture in 1959 by the group of Hayaishi. Fifteen years passed before the same strain was found to be capable of degrading toluene, $m$-xylene, $p$-xylene and a number of other di- and tri-alkylsubstituted benzenes (Worsey \& Williams, 1975; Kunz \& Chapman, 1981; Assinder \& Williams, 1990). The observation that the toluene catabolic genes are located

Abbreviations: $a_{A}^{0}$, specific affinity; $D$, dilution rate; $K_{m}$, MichaelisMenten constant; $K_{\mathrm{s}}$, Monod constant; $K_{\mathrm{T}}$, half-saturation constant for uptake; $V_{\max }$ maximal conversion rate. on a large catabolic plasmid (designated TOL plasmid pWW0), and the apparent importance of the so-called TOL pathway in the natural attenuation of the aromatic fraction of spilled oil-products, caused $P$. putida $\mathrm{mt}-2$ to become one of the most intensively studied bacterial strains of the last two decades (reviewed by Assinder \& Williams, 1990; Marqués et al., 1994; Ramos et al., 1997).

In soil samples taken from various petrol-contaminated sites, $30-50 \%$ of the toluene-degrading bacterial population harbours a TOL pathway (as determined by oxygen-uptake experiments; unpublished results). In environments contaminated with oil-products, toluene and the xylenes are often present together (Chapelle, 
1993). However, it is unknown to what extent toluene and to what extent di-and tri-alkylsubstituted benzenes contribute to the total flux through the TOL pathway under such mixed-substrate conditions. To investigate this question we compared the degradation kinetics $\left(V_{\max }, K_{\mathrm{T}}\right.$, specific affinity) for the three substrates of the TOL pathway that are quantitatively the most important in oil products (toluene, $m$-xylene and $p$-xylene: see Chapelle, 1993). In addition, we studied the (maximum) flux of intermediates of these compounds through the first steps of the TOL pathway.

\section{METHODS}

Bacterial strain. P. putida mt-2 (ATCC 33015) harbouring the TOL plasmid $\mathrm{pWW}$, hereafter referred to as $P$. putida (pWW0), was stored in a $20 \%(\mathrm{v} / \mathrm{v})$ glycerol culture at $-70{ }^{\circ} \mathrm{C}$.

Culture medium. The composition of the mineral-salts medium used for cultivation of the strain under carbon limitation in chemostat culture was described previously (Duetz et al., 1991).

Chemostat culture. The fermenters used were custom-made, shaped like an Erlenmeyer flask, and had a working volume of $105 \pm 5 \mathrm{ml}$. Details of the fermenter can be found in Duetz et al. (1996). The temperature was maintained at $28 \pm 1^{\circ} \mathrm{C}$. $m$ $\mathrm{Xylene}$ or toluene were supplied by mixing the main airflow $\left(6 \mathrm{l} \mathrm{h}^{-1}\right)$ with air saturated $\left(\right.$ at $\left.0^{\circ} \mathrm{C}\right)$ with $m$-xylene $\left(300 \mathrm{ml} \mathrm{h}^{-1}\right)$ or toluene $\left(70 \mathrm{ml} \mathrm{h}^{-1}\right)$, corresponding to an inflow of 24.0 and $25 \cdot 2 \mu \mathrm{mol} \mathrm{h}{ }^{-1}$ respectively. The operational dilution rate $(D)$ was $0.05 \mathrm{~h}^{-1}$.

Analysis of $\boldsymbol{m}$-xylene and toluene in the gas phase by GC. The percentage of $m$-xylene and toluene that was converted in the fermenter was calculated from the peak areas resulting from the injection of $250 \mu \mathrm{l}$ samples of the incoming air and the headspace of the fermenter in a Hewlett Packard type 5890 gas chromatograph equipped with an HP101 methylsilicone capillary column $(25 \mathrm{~m})$, a split injector $(1: 7)$ (both at $100^{\circ} \mathrm{C}$ ) and a flame ionization detector. A gas-tight glass syringe (SGE, Melbourne, Australia) with a stainless steel plunger (with no Teflon parts) was used for injection. The retention times for toluene, $m$-xylene and $p$-xylene were $1 \cdot 4,1 \cdot 7$ and 1.7 min, respectively.

Analysis of pathway intermediates. Samples were taken from a fermenter and filtered through a $0.22 \mu \mathrm{m}$ filter within $5 \mathrm{~s}$. For analysis of the benzyl alcohols, benzaldehydes, benzoates, dihydrodiols and catechols, samples of $1 \mu$ l were injected into an HPLC apparatus equipped with a variable-wavelength detector (Hewlett Packard 1050 series) set at $195 \mathrm{~nm}$ and a $10 \mathrm{~cm}$ Hypersil C18 column (Chrompack). The solvent was acetonitrile $/ 5 \mathrm{mM} \mathrm{H}_{2} \mathrm{SO}_{4}(86: 14, \mathrm{v} / \mathrm{v})$ run at a flow rate of $0.4 \mathrm{ml} \mathrm{min}^{-1}$.

Biomass concentration. The $\mathrm{OD}_{540}$ of chemostat cultures was measured regularly. As described in a previous study (Duetz et al., 1996) no significant influence of the growth condition on the relationship between the data for the dry weight and $\mathrm{OD}_{540}$ values was found; under all conditions tested, an $\mathrm{OD}_{540}$ of 1.0 corresponded to a dry weight of $380 \pm 10 \mathrm{mg} \mathrm{l}^{-1}$, which was used to estimate the dry weight from the $\mathrm{OD}_{540}$ data.

Determination of the conversion kinetics of toluene, $\boldsymbol{m}$ - and p-xylene. The substrate-depletion method as described by Robinson \& Characklis (1984) was used to determine the degradation kinetics $\left(V_{\max }, K_{\mathrm{T}}\right.$, specific affinity) of the volatile substrates of the TOL pathway. Cells were harvested from a chemostat culture, diluted and transferred to a headspace vial. The suspension was stirred vigorously and supplied with toluene, $m$-xylene or $p$-xylene through the gas phase. The concentration was monitored by manual injection of $250 \mu \mathrm{l}$ of the headspace into a gas chromatograph (as described above) every $2-4 \mathrm{~min}$, using a gas-tight syringe. Further details of the technical and mathematical procedures can be found in Duetz et al. (1997).

Determination of the flux of intermediates through the TOL pathway. A $5 \mathrm{ml}$ sample of cells of P. putida (pWW0) was harvested from a $m$-xylene-limited chemostat culture $(D=$ $\left.0.05 \mathrm{~h}^{-1}\right)$ and mixed with an equal volume of sterile mineral medium in a thermostatically controlled $\left(28^{\circ} \mathrm{C}\right) 50 \mathrm{ml}$ Erlenmeyer flask. Subsequently, the cell suspension was supplied with 400-500 $\mu \mathrm{M}$ benzyl alcohol, 3-methylbenzyl alcohol, benzaldehyde or 3-methylbenzaldehyde. At $5 \mathrm{~min}$ intervals, $1 \mathrm{ml}$ samples were filtered through a $0.22 \mu \mathrm{m}$ filter and stored at $0{ }^{\circ} \mathrm{C}$ for later analysis by HPLC as described above. The specific fluxes of the compounds through the various steps of the TOL pathway were calculated from measures of changes in substrate concentrations with time.

\section{RESULTS}

P. putida (pWW0) was grown in chemostat culture at a dilution rate of $0.05 \mathrm{~h}^{-1}$ with either toluene or $m$-xylene as a growth-limiting carbon source. The cell densities under steady-state conditions were between $0 \cdot 19$ and $0.23 \mathrm{~g}$ dry wt $\mathrm{l}^{-1}$. The actual fluxes of toluene and $m$ xylene in the chemostat cultures were 1.5 and $1.3 \mathrm{mmol}$ $\mathrm{h}^{-1}(\mathrm{~g} \text { dry } \mathrm{wt})^{-1}$, respectively. Expressed in mass units, the fluxes for both compounds were identical: $0 \cdot 14 \mathrm{~g} \mathrm{~h}^{-1}$ $(\mathrm{g} \text { dry wt })^{-1}$. No metabolites were detected in the culture supernatants.

\section{Kinetics of toluene, $\boldsymbol{m}$-xylene and $\boldsymbol{p}$-xylene utilization}

The substrate-depletion method of Robinson \& Characklis (1984) using headspace sampling was used to prepare $v$ vs $s$ curves for the three hydrocarbons. The applicability of this method is dependent on the continuous equilibrium between the gas phase and the liquid phase. The latter was proven by supplying the liquid phase with $20 \mu \mathrm{l}$ phosphoric acid in the middle of a run (stopping the activity of the cells), resulting in the instantaneous halting of the decrease in the $m$-xylene concentration in the gas phase. $v$ vs $s$ curves for $m$ xylene and $p$-xylene utilization were made using cells harvested from the $m$-xylene-limited chemostat culture (Fig. 1). The $v$ vs $s$ curve for toluene utilization as presented in Fig. 1 was derived in an identical way using cells harvested from the toluene-limited chemostat. The $v$ vs $s$ curve for toluene utilization by cells harvested from a $m$-xylene-limited chemostat culture was almost identical at low concentrations of toluene, but maximal conversion rates were $40-50 \%$ lower (not shown). Values for the specific affinity $\left(a_{\mathrm{A}}^{0}\right.$, the slope of the $v$ vs $s$ curve near the origin), the maximal conversion rate $\left(V_{\max }\right)$ and the half-saturation constant $\left(K_{\mathrm{T}}\right)$ were derived from the $v$ vs $s$ curves by fitting the MichaelisMenten equation to the data points (note: the use of the parameter $K_{\mathrm{T}}$ does not imply the assumption of an active transport system for the hydrocarbons). The $v$ vs 


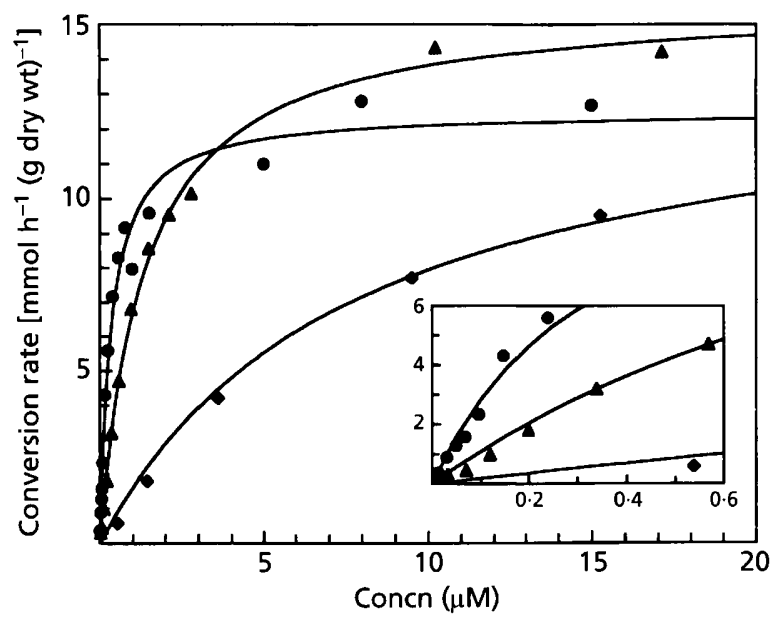

Fig. 1. Influence of the concentration of $m$-xylene (O), $p$-xylene $(\Delta)$ and toluene ( $\bullet$ ) on the rate of conversion ( $v$ vs $s$ curve) by cells of $P$. putida (pWWO) harvested from chemostat cultures ( $D$ $=0.05 \mathrm{~h}^{-1}$ ) as described in the text. The data points were derived from substrate-depletion curves and fitted with the Michaelis-Menten equation by the non-linear least-squares method, yielding data for $K_{\mathrm{s}}$ and $V_{\max }$ as included in Table 1. Inset: expansion of data for lower $s$ values.

$s$ curves appeared to be indistinguishable from linear at low concentrations of the substrate (Fig. 1). Therefore, alternative values for $a_{\mathrm{A}}^{0}$ were calculated by linear regression on all data points at substrate concentrations less than $30 \%$ of $K_{\mathrm{T}}$. The values for $a_{\mathrm{A}}^{0}$ were found to be approximately 20 times higher for $m$-xylene than for toluene (irrespective of which calculation method was used). $p$-Xylene showed intermediate values for $a_{\mathrm{A}}^{0}$. The $V_{\max }$ values observed for the three hydrocarbons showed no significant differences (based on the single standard errors, see Table 1).

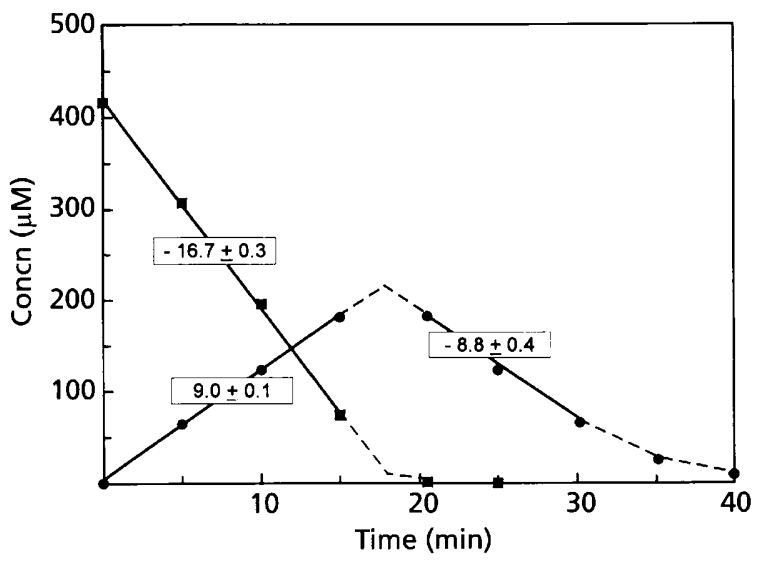

Fig. 2. Consumption of 3-methylbenzyl alcohol $(\mathbb{E})$ and the transient accumulation of 3-methylbenzoate (O) by a cell suspension $\left(81.7 \mathrm{mg}\right.$ dry wt $\mathrm{I}^{-1}$ ) of $P$. putida (pWW0) harvested from a $m$-xylene-limited chemostat $\left(D=0.05 \mathrm{~h}^{-1}\right)$. The framed numbers indicate the rates of consumption or synthesis expressed as $\mathrm{mmol} \mathrm{h}^{-1}$ ( $\mathrm{g}$ dry $\left.\mathrm{wt}\right)^{-1}$ as calculated by linear regression on the data points connected by the solid lines. The broken lines show assumed consumption or synthesis patterns.

\section{Flux of intermediates through the TOL pathway}

Cell suspensions of $P$. putida ( $\mathrm{pWW} 0$ ) were spiked with $35 \mu \mathrm{M}$ toluene or $m$-xylene, or with $450 \pm 50 \mu \mathrm{M}$ benzyl alcohol, 3-methylbenzyl alcohol, benzaldehyde or 3methylbenzaldehyde. The changes in concentrations of these compounds, and all other possible intermediates between the hydrocarbons and the catechols, were monitored. During conversion of toluene, no intermediates were detected. During conversion of $m$-xylene, 3-methylbenzoate was the only intermediate that accumulated at measurable concentrations [at a rate of approximately $2 \mathrm{mmol} \mathrm{h}^{-1}(\mathrm{~g} \text { dry } \mathrm{wt})^{-1}$ ]. When the cell

Table 1. Maximal conversion rates $\left(V_{\max }\right)$, half-saturation constants $\left(K_{T}\right)$ and specific affinities $\left(a_{A}^{0}\right)$ for $m$-xylene, $p$-xylene and toluene of cells harvested from chemostat cultures of $P$. putida (pWW0)

The values were derived by non-linear least-square fitting of the Michaelis-Menten equation to all data points of the $\nu$ vs $s$ curves (Fig. 1). Alternative values for $a_{\mathrm{A}}^{0}$ were derived by linear regression of the data points with values for $v$ below $30 \%$ of $V_{\max }$. Alternative values for $V_{\max }$ were calculated by linear regression on a substrate depletion curve including all data points for which the substrate concentration is more than $300 \%$ higher than the $K_{\mathrm{T}}$ value. Values are shown \pm single standard errors. ND, Not determined.

\begin{tabular}{|llllc|}
\hline Compound & \multicolumn{1}{c}{$\begin{array}{c}\text { Calculation } \\
\text { method }\end{array}$} & $\begin{array}{c}V_{\max }\left[\mathrm{mmol} \mathrm{h}^{-1}\right. \\
\left.(\mathbf{g ~ d r y ~ w t})^{-1}\right]\end{array}$ & $\boldsymbol{K}_{\mathrm{T}}(\boldsymbol{\mu M})$ & $\begin{array}{c}\boldsymbol{a}_{\mathrm{A}}^{0}\left[\mathbf{1}(\mathrm{g} \mathrm{dry} \mathrm{wt})^{-1}\right. \\
\left.\mathbf{h}^{-1}\right]\end{array}$ \\
\hline Toluene & Michaelis-Menten & $14 \cdot 1 \pm 1 \cdot 0$ & $7 \cdot 7 \pm 1 \cdot 7$ & $1820 \pm 240^{*}$ \\
& Linear regression & $11 \cdot 2 \pm 0 \cdot 5$ & $\mathrm{ND}$ & $1300 \pm 20$ \\
-Xylene & Michaelis-Menten & $12 \cdot 5 \pm 0 \cdot 4$ & $0 \cdot 34 \pm 0 \cdot 04$ & $36950 \pm 120^{*}$ \\
& Linear regression & $12 \cdot 8 \pm 0 \cdot 2$ & $\mathrm{ND}$ & $24700 \pm 960$ \\
& Michaelis-Menten & $15 \cdot 7 \pm 0 \cdot 3$ & $1 \cdot 3 \pm 0 \cdot 1$ & $11800 \pm 60^{*}$ \\
& Linear regression & $14 \cdot 3 \pm 0 \cdot 6$ & $\mathrm{ND}$ & $9170 \pm 180$ \\
\hline
\end{tabular}

* Calculated as $V_{\max } / K_{\mathrm{T}}$ (see Button 1985, 1993). 


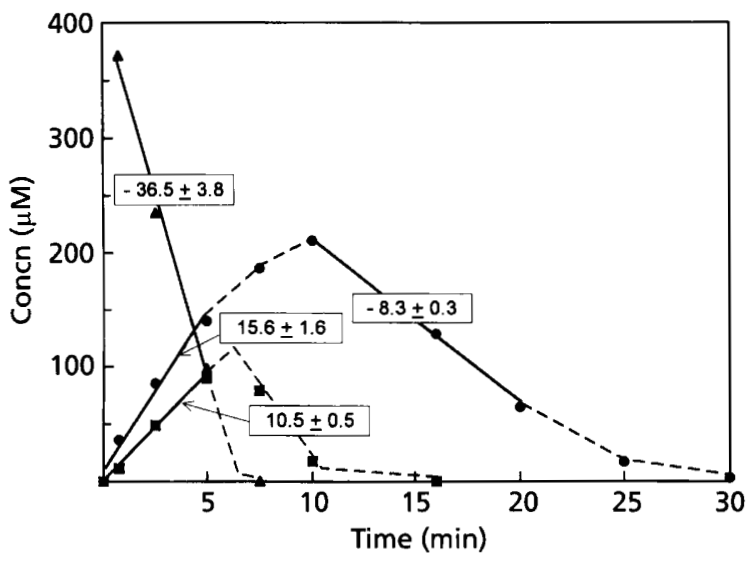

Fig. 3. Consumption of 3-methylbenzylaldehyde $(\mathbf{A})$ and the transient accumulation of 3-methylbenzyl alcohol ( $\mathbf{\square}$ ) and 3methylbenzoate $(\Theta)$ by a cell suspension (104 mg dry wt $\mathrm{I}^{-1}$ ) of $P$. putida (pWW0) harvested from a $m$-xylene-limited chemostat $\left(D=0.05 \mathrm{~h}^{-1}\right)$. The framed numbers indicate the rates of consumption or synthesis expressed as $\mathrm{mmol} \mathrm{h}^{-1}$ (g dry wt) ${ }^{-1}$ as calculated by linear regression on the data points connected by the solid lines. The broken lines show assumed consumption or synthesis patterns.
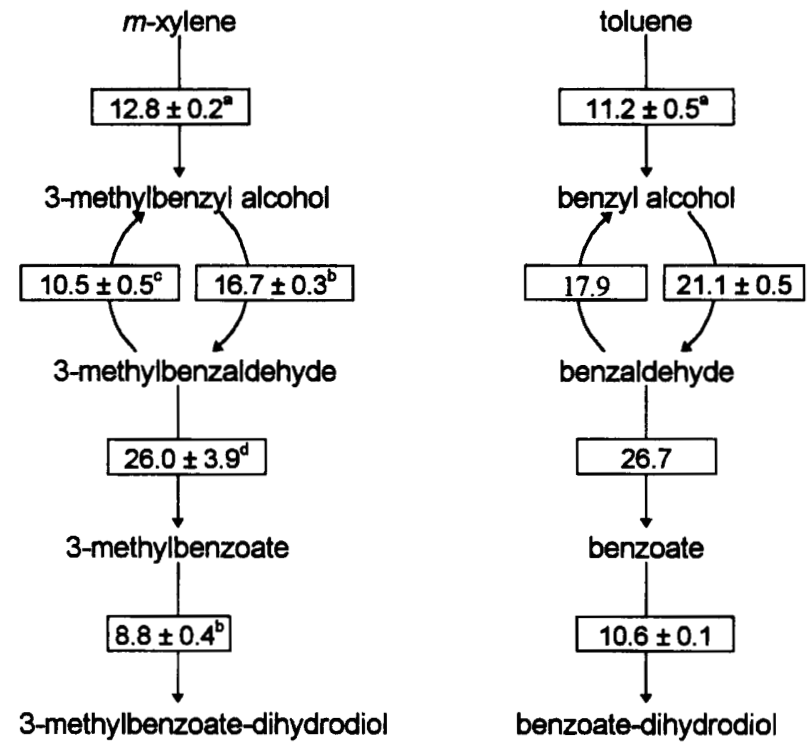

Fig. 4. Maximal-flux diagram for $m$-xylene, toluene and their intermediates through the upper pathway and the first step of the meta-pathway. The superscript letters indicate the experiments from which the values were derived: $a$, the experiment depicted in Fig. $1 ; b$, the experiment depicted in Fig. $2 ; c$, the experiment depicted in Fig. 3 ; $d$, the maximal consumption rate of 3-methylbenzaldehyde minus the initial formation rate of 3-methylbenzaldehyde measured in the experiment depicted in Fig. 3. The rates for toluene and its intermediates were derived from similar experiments (not shown in figures).

suspension was supplied with 3-methylbenzyl alcohol, 3-methylbenzoate was found to accumulate transiently but no 3-methylbenzaldehyde was detected (Fig. 2).

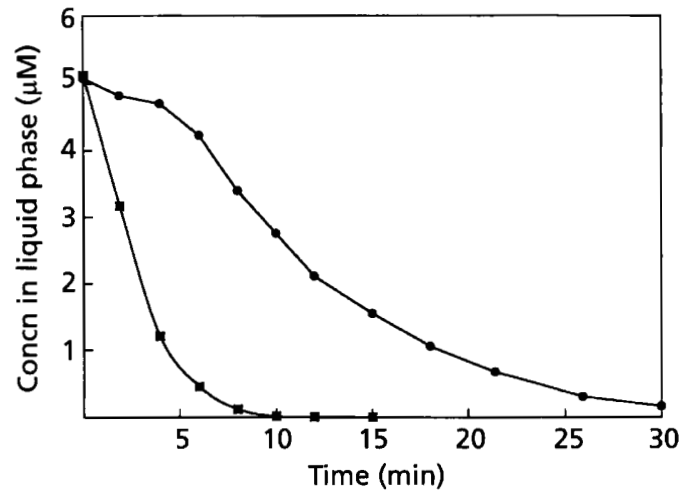

Fig. 5. Simultaneous consumption of toluene ( $)$ and $m$-xylene (D) by cells harvested from a $m$-xylene-limited chemostat culture.

When the cells were supplied with 3-methylbenzaldehyde, both 3-methylbenzyl alcohol (due to the reverse action of 3-methylbenzyl alcohol dehydrogenase) and 3-methylbenzoate accumulated transiently (Fig. 3 ). The framed numbers in Figs 2 and 3 refer to the (mean) consumption or synthesis rates of the compounds in the time intervals indicated by the solid lines. Similar patterns were found after pulses of benzyl alcohol and benzaldehyde. The observed rates of consumption and synthesis of substrates and intermediates were used to compose a maximal-flux diagram for the upper pathway and the first step of the meta-pathway [the conversion of (methyl) benzoate to the corresponding dihydrodiol] (Fig. 4).

\section{Simultaneous consumption of toluene and $m$-xylene}

Cells harvested from the $m$-xylene-limited chemostat culture were supplied with $5 \mu \mathrm{M}$ toluene and $5 \mu \mathrm{M} \mathrm{m}$ xylene simultaneously and the concentration of these substrates was followed with time. The consumption of $m$-xylene started immediately at a rate comparable to the rate when $m$-xylene was the sole substrate. The consumption rate of toluene was very low until the concentration of $m$-xylene had decreased to below approximately $0.5 \mu \mathrm{M}$ (Fig. 5). A similar pattern was found with cells harvested from a toluene-limited chemostat (data not shown).

\section{Inhibition of the conversion of $m$-xylene by methylbenzyl alcohol}

The $V_{\max }$ for $m$-xylene displayed by cells harvested from a $m$-xylene-limited chemostat was found to be lowered by the presence of methylbenzyl alcohol, the product of the first step of the TOL pathway (Fig. 6). The concentration of methylbenzyl alcohol causing a $50 \%$ inhibition of the conversion rate was approximately $300 \mu \mathrm{M}$. 


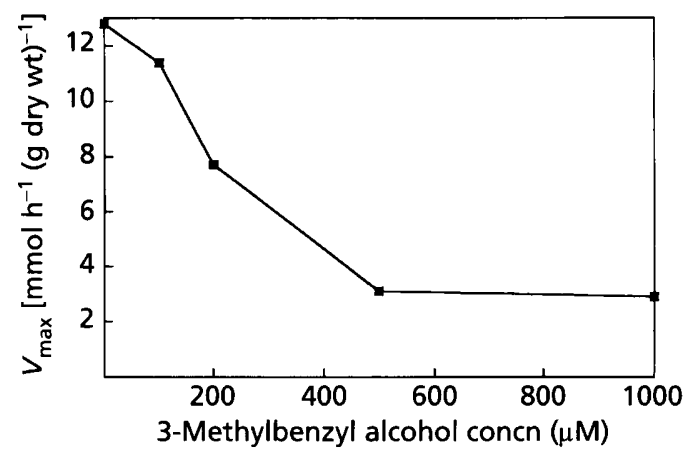

Fig. 6. Inhibition of the maximal $m$-xylene conversion rate by methylbenzyl alcohol. The cells used were harvested from a $\mathrm{m}$ xylene-limited chemostat $\left(D=0.05 \mathrm{~h}^{-1}\right)$.

\section{DISCUSSION}

The kinetics of biodegradation of various substrates of the TOL upper pathway were compared. The cells used were harvested from chemostat cultures grown under either $m$-xylene or toluene limitation. These growth conditions were previously found to result in relatively stable and high expression levels of the upper pathway [1250-1500 $\mathrm{mU}$ (mg protein $)^{-1}$ as measured by benzyl alcohol dehydrogenase activity; Duetz et al., 1997).

Individual $v$ vs $s$ curves for toluene, $m$-xylene and $p$ xylene were derived from substrate-depletion curves. The data points at substrate concentrations above $K_{\mathrm{s}}$ fitted well with the Michaelis-Menten equation (Fig. 1). In the area below $K_{\mathrm{s}}$, however, the relationship between $v$ and $s$ was indistinguishable from linearity, especially for $m$-xylene and $p$-xylene. A similar deviation from Michaelis-Menten kinetics has previously been observed in many cases (reviewed by Dabes et al., 1973; Koch, 1982). Diffusion limitation has been put forward as a possible explanation if the specific affinity $\left(a_{\mathrm{A}}^{0}\right.$, the slope of the $v$ vs $s$ curve near the origin) observed is relatively high (Koch, 1982). Button (1993) modelled diffusion of substrates to the cell surface. Using his models it can be calculated that cells the size of pseudomonads may attain maximal (diffusion-limited) $a_{\mathrm{A}}^{0}$ values for compounds like toluene in the order of $60000 \mathrm{l} \mathrm{h}^{-1}(\mathrm{~g} \text { dry wt })^{-1}$. The $a_{\mathrm{A}}^{0}$ for $m$-xylene in this study $\left[24700 \mathrm{~h}^{-1}(\mathrm{gdry} \mathrm{wt})^{-1}\right]$ is close to this theoretical threshold value, indicating that diffusion limitation could play a role. A practical consequence of the linearity of the $v$ vs $s$ curve near the origin is the systematic overestimation of $a_{\mathrm{A}}^{0}$ when derived from fitting the data to the Michaelis-Menten equation. We assume therefore that the (22-33\% lower) values for $a_{\mathrm{A}}^{0}$ derived by linear regression of the data points near the origin (see Table 1) are more reliable than the values derived from fitting all data points to the Michaelis-Menten equation. The $a_{\mathrm{A}}^{0}$ observed for $m$-xylene was almost 20 -fold higher than the $a_{\mathrm{A}}^{0}$ for toluene $\left[1300 \mathrm{l} \mathrm{h}^{-1}(\mathrm{~g} \text { dry wt })^{-1}\right]$. No published data for the $a_{\mathrm{A}}^{0}$ for $m$-xylene by pure cultures are available. For toluene, $a_{\mathrm{A}}^{0}$ values were determined using cells of $P$. putida $\mathrm{F} 1$ (carrying the tod pathway) grown in batch culture (Robertson \& Button, 1987). The maximal values for $a_{\mathrm{A}}^{0}$ they observed were around $1000 \mathrm{l} \mathrm{h}^{-1}(\mathrm{~g}$ dry wt $)^{-1}$. These values for $a_{\mathrm{A}}^{0}$ are similar to the data presented in our study but care should be taken in comparing them; apart from the difference in degradation pathway between the two strains, the difference in the cultivation method of the cells should also be taken into account. Earlier studies have shown that cells pre-grown at maximal growth rate exhibit a lower expression level of the catabolic pathways involved (and consequently a lower $a_{\mathrm{A}}^{0}$ ) than cells grown under carbonlimited conditions in chemostat culture (Duetz et al., 1997; Harder \& Dijkhuizen, 1983).

The relatively high $a_{\mathrm{A}}^{0}$ values for the xylenes (in comparison to that of toluene) found in our study suggest that the role of the TOL pathway in nature, where substrate concentrations are generally low, lies mainly in its capacity to channel xylenes and perhaps other di- or tri-alkylsubstituted benzenes into central metabolism. The sequential utilization of low concentrations of $m$-xylene and toluene when added simultaneously to a cell suspension (Fig. 5) confirms the preferred consumption of the xylenes. A relatively minor role of the TOL pathway in natural toluene degradation was also suggested by our previous finding that $P$. putida (pWW0) was the least competitive strain among four different toluene-degrading soil bacteria when grown under toluene or oxygen limitation (Duetz et al., 1994).

The $V_{\max }$ values for toluene, $m$-xylene and $p$-xylene showed no significant differences, as was also observed by Abril et al. (1989). The absolute values for $V_{\max }$ measured were approximately 10 times higher than the flux in the fermenters from which the cells were harvested. Such an overcapacity for the uptake of a growth-limiting substrate is common under carbonand energy-limiting growth conditions (Harder \& Dijkhuizen, 1983). These high specific consumption rates are probably not attained in the natural environment, even when it is heavily contaminated with oil products. This is because the maximal (equilibrium) concentration of toluene and xylenes in the aqueous phase is as low as $1-10 \mu \mathrm{M}$ due to their tendency to partition in the oil phase (Chapelle, 1993; Kappeler \& Wuhrman, 1978). The concentrations encountered by bacterial populations at some distance from the wateroil interface may be substantially lower than the equilibrium concentration due to low diffusion rates.

An additional goal of the present study was to assess to what extent the various enzymic steps control the total flux through the TOL pathway or, in other words, which enzymes may be considered as 'bottlenecks'. A flux study on the TOL upper pathway is relatively uncomplicated since the intermediates are rather lipophilic and can presumably diffuse passively through the cell membrane. After a pulse of 3-methylbenzyl alcohol, 3-methylbenzoate continued to accumulate in the supernatant until 3-methylbenzyl alcohol was fully utilized (Fig. 2). The subsequent reuptake of 3-methylbenzoate occurred at a rate about $50 \%$ of the maximal 3methylbenzyl alcohol conversion rate. The intermediate, 
3-methylbenzaldehyde, did not accumulate at measurable levels (less than $0.5 \mu \mathrm{M}$ ), indicating that the maximal in vivo activity of benzaldehyde dehydrogenase was higher than that of the previous enzyme benzyl alcohol dehydrogenase. This was consistent with the observation that 3-methylbenzaldehyde, after it was pulsed to a cell suspension, was converted to 3methylbenzoate at a higher rate $\left[26 \mathrm{mmol} \mathrm{h}^{-1}(\mathrm{~g}\right.$ dry $\mathrm{wt})^{-1}$; see Fig. 3] than the consumption rate observed for 3 -methylbenzyl alcohol $\left[21 \cdot 1 \mathrm{mmol} \mathrm{h}^{-1}(\mathrm{~g} \text { dry wt })^{-1}\right.$, see Fig. 2]. The transient accumulation of 3-methylbenzyl alcohol, as observed after a pulse of 3-methylbenzaldehyde, was probably due to the reverse action of benzyl alcohol dehydrogenase. No accumulation of (methyl)benzoate cis-glycol or (methyl)catechol was observed in any experiment (results not shown), suggesting that the cis-glycol dehydrogenase and catechol 2,3-dioxygenase steps occurred at rates equal to that of (methyl)benzoate consumption. That this is not always the case was shown by Ampe \& Lindley (1995), who observed accumulation of catechol during growth of Alcaligenes eutrophus on benzoate.

The $25 \%$ faster conversion of benzyl alcohol in comparison to methylbenzyl alcohol is in qualitative agreement with the relative activity of purified benzyl alcohol dehydrogenase on these two substrates $(8 \%$ faster conversion of benzyl alcohol) as reported by Shaw \& Harayama (1990). The same research group found no significant difference between the activities of purified benzaldehyde dehydrogenase on benzaldehyde and 3methylbenzaldehyde (Inoue et al., 1995), which is also consistent with the present results (Fig. 4). Apparently inconsistent with the present study, however, is their observed $K_{\mathrm{m}}$ value for benzyl alcohol of $220 \mu \mathrm{M}$ (Shaw \& Harayama, 1990). If the $K_{\mathrm{m}}$ were similarly high in vivo, benzyl alcohols would have accumulated to detectable levels during the conversion of the hydrocarbons, which was actually not the case. A possible explanation is that the $K_{\mathrm{m}}$ value of Shaw \& Harayama $(1990)$ is an overestimation, caused by product inhibition, which may not be occurring in vivo where benzaldehyde is immediately converted to benzoate.

We may conclude from the flux experiments that the initial monooxygenation step is in vivo the slowest step of the upper pathway (see also Fig. 4). This situation may be assumed to be independent of the level of expression since the encoding genes of the upper pathway are organized in a single operon. It may be that the significant overcapacity of the two dehydrogenation steps reflects the limited ability of the strain to actively regulate the ratio between the enzymes. A second possibility is that the relative expression levels of the enzymes of the TOL pathway have actually been optimized in the course of evolution through posttranscriptional regulation systems (e.g. by differences in half-lives of various mRNA regions and enzymes). The function of the relatively high activities of the dehydrogenases could be the fast and efficient removal of (methyl)benzyl alcohol. In this way the degree of product inhibition of xylene monooxygenase is minimized and so its in vivo activity is optimized. A restricted expression of xylene monooxygenase may be essential for the cell in the light of the observation that high expression levels of monooxygenases can cause damage to the cell membrane (Nieboer et al., 1993). This damage, even when not lethal, might lead to an increase in the maintenance-energy requirement and so diminish the competitiveness of the strain.

Whereas the xylene oxygenase may be assumed to limit the flux through the upper pathway independent of the growth conditions, the situation is different with respect to the first enzyme of the meta pathway, toluate 1,2dioxygenase. When, as in the present study, cells are used that were pre-grown under $m$-xylene limitation, the maximal in vivo activity of this enzyme was found to be much lower than that of the two previous steps. Under other growth conditions, such as nitrogen, phosphate or sulphate limitation, however, the expression of the meta pathway was found to be relatively high in comparison to the upper pathway (Duetz et al., 1997). As a consequence, the activity of toluate 1,2dioxygenase may not - or may to a lower extent - limit the flux under those growth conditions. On the other hand, the extent to which toluate 1,2-dioxygenase (and also xylene monooxygenase) limits the flux may be stronger under natural conditions (e.g. in soil) since oxygen is generally not present at air-saturated levels as in this study. Suboptimal concentrations of oxygen may have a significant impact on the activity of oxygenases as their $K_{\mathrm{m}}$ values for oxygen are generally rather high (10-60 $\mu \mathrm{M}$, corresponding to $4-25 \%$ of the air-saturated concentration: Shaler \& Klecka, 1985).

Kinetic data such as presented here for the TOL pathway could be helpful in modelling the disappearance of the various BTEX compounds as a function of the size and composition of the BTEX-degrading population. The $a_{\mathrm{A}}^{0}$ values for various compounds may be of particular assistance in anticipating the residual concentrations that may finally be attained.

\section{ACKNOWLEDGEMENTS}

We thank Astrid Mars and Wim de Koning from the University of Groningen for their advice on the application of the substrate-depletion method. This research was supported by an EU-ENVIRONMENT grant (EV5V-CT94-0539).

\section{REFERENCES}

Abril, M. A., Michan, C., Timmis, K. N. \& Ramos, J. L. (1989). Regulator and enzyme specificities of the TOL plasmid-encoded upper pathway for degradation of aromatic hydrocarbons and expansion of the substrate range of the pathway. J Bacteriol 171, $6782-6790$.

Ampe, F. \& Lindley, N. D. (1995). Acetate utilization is inhibited by benzoate in Alcaligenes eutrophus: evidence for transcriptional control of the expression of acoE coding for acetyl coenzyme A synthetase. J Bacteriol 177, 5826-5833.

Assinder, S.J. \& Williams, P. A. (1990). The TOL plasmids: determinants of the catabolism of toluene and the xylenes. $A d v$ Microb Physiol 31, 1-69. 
Button, D. K. (1985). Kinetics of nutrient-limited transport and microbial growth. Microbiol Rev 49, 270-297.

Button, D. K. (1993). Nutrient-limited microbial growth: overview and recent advances. Antonie Leeuwenhoek 63, 225-235.

Chapelle, F. H. (1993). Ground-Water Microbiology and Geochemistry. New York: Wiley.

Dabes, J. N., Finn, R. K. \& Wilke, C. R. (1973). Equations of substrate-limited growth: the case for Blackman kinetics. Biotechnol Bioeng 15, 1159-1177.

Duetz, W. A., Winson, M. K., Van Andel, J. G. \& Williams, P. A. (1991). Mathematical analysis of catabolic function loss in a population of Pseudomonas putida mt-2 during growth on benzoate. J Gen Microbiol 137, 1363-1368.

Duetz, W. A., Marqués, S., De Jong, C., Ramos, J. L. \& Van Andel, J. G. (1994). Inducibility of the TOL catabolic pathway in Pseudomonas putida ( $\mathrm{pWW}$ ) growing on succinate in continuous culture: evidence of carbon catabolite repression control. $J$ Bacteriol 176, 2354-2361.

Duetz, W. A., Marqués, S., Wind, B., Ramos, J. L. \& Van Andel, J. G. (1996). Catabolite repression of the toluene degradation pathway in Pseudomonas putida (pWW0) under various conditions of nutrient limitation in chemostat culture. Appl Environ Microbiol 62, 601-606.

Duetz, W. A., Wind, B., Kamp, M. \& Van Andel, J. G. (1997). Effect of growth rate, nutrient limitation and presence of succinate on expression of TOL pathway enzymes in response to $m$-xylene in chemostat cultures of Pseudomonas putida ( $\mathrm{pWW0}$ ). Microbiology 143, 2331-2338.

Harder, W. \& Dijkhuizen, L. (1983). Physiological responses to nutrient limitation. Annu Rev Microbiol 38, 1-23.

Inoue, J., Shaw, J. P., Rekik, M. \& Harayama, S. (1995). Overlapping substrate specificities of benzaldehyde dehydrogenase (the $x y l C$ gene product) and 2-hydroxymuconic semialdehyde dehydrogenase (the $x y l G$ gene product) encoded by TOL plasmid pWW0 of Pseudomonas putida. J Bacteriol 177, 1196-1201.

Kappeler, T. \& Wuhrman, K. (1978). Microbial degradation of the water soluble fraction of gas oil. Water Res 12, 327-333.

Koch, A. L. (1982). Multistep kinetics: choice of models for the growth of bacteria. J Theor Biol 98, 401-417.
Kunz, P. A. \& Chapman, P. J. (1981). Catabolism of pseudocumene and 3-ethyltoluene by Pseudomonas putida mt-2: evidence for new functions of the TOL plasmid pWW0. J Bacteriol 146, 179-191.

Marqués, S., Holtel, A., Timmis, K. N. \& Ramos, J. L. (1994). Transcriptional induction kinetics from the promoters of the catabolic pathways of TOL plasmid pWW0 of Pseudomonas putida for metabolism of aromatics. J Bacteriol 176, 2517-2524.

Nieboer, M., Kingma, J. \& Witholt, B. (1993). The alkane oxidation system of Pseudomonas oleovorans: induction of the alk genes in Escherichia coli W3110 affects membrane biogenesis and results in overexpression of alkane hydroxylase in a distinct cytoplasmic membrane subfraction. Mol Microbiol 8, 1039-1051.

Ramos, J. L., Marques, S. M. \& Timmis, K. N. (1997). Transcriptional control of the Pseudomonas TOL plasmid catabolic operons is achieved through an interplay of host factors and plasmid encoded regulators. Annu Rev Microbiol 51, 341-373.

Robertson, B. R. \& Button, D. K. (1987). Toluene induction and uptake kinetics and their inclusion in the specific affinity relationship for describing rates of hydrocarbon metabolism. Appl Environ Microbiol 53, 2193-2205.

Robinson, J. A. \& Characklis, W. G. (1984). Simultaneous estimation of $V_{\max }, K_{\mathrm{m}}$, and the rate of endogenous substrate production $(R)$ from substrate depletion data. Microb Ecol 10, 165-178.

Shaler, T. A. \& Klecka, G. M. (1985). Effects of dissolved oxygen concentration on biodegradation of 2,4-dichlorophenoxyacetic acid. Appl Environ Microbiol 51, 950-955.

Shaw, J. P. \& Harayama, S. (1990). Purification and characterisation of TOL plasmid-encoded benzyl alcohol dehydrogenase and benzaldehyde dehydrogenase of Pseudomonas putida. Eur J Biochem 191, 705-714.

Worsey, M. J. \& Williams, P. A. (1975). Metabolism of toluene and xylenes by Pseudomonas putida (arvilla) $\mathrm{mt}-2$ : evidence for a new function of the TOL plasmid. J Bacteriol 124, 7-13.

Received 8 August 1997; revised 22 November 1997; accepted 17 March 1998. 